\title{
Aplikasi Pemupukan Organik dan Hayati di Sawah Kabupaten Tasikmalaya, Jawa Barat
}

\author{
Reginawanti Hindersah ${ }^{1}$, Sondi Kuswaryan ${ }^{2}$ \\ ${ }^{1}$ Fakultas Pertanian, Universitas Padjadjaran \\ ${ }^{2}$ Fakultas Peternakan, Universitas Padjadjaran \\ Email: reginawanti@unpad.ac.id ${ }^{1}$, sondi.kuswaryan@unpad.ac.id ${ }^{2}$ \\ ${ }^{1}$ Penulis korespondensi
}

\begin{abstract}
ABSTRAK
Sebagian sawah di Kecamatan Sukaratu, Kabupaten Tasikmalaya tertimbun material letusan Gunung Galunggung pada 1982 sehingga kualitas sawah tidak sebaik sebelum letusan. Peningkatan kualitas tanah sawah dapat dilakukan dengan bahan organik dan pupuk hayati. Tujuan Pengabdian kepada Masyarakat ini adalah memberikan pengetahuan dasar tentang pupuk hayati kepada petani di desa Sinagar dan Linggajati serta meningkatkan keterampilan petani dalam aplikasi pupuk hayati disertai kompos. Untuk mencapai tujuan tersebut, telah dilakukan diskusi kelompok terfokus dan penyuluhan mengenai pupuk hayati, praktek pembuatan kompos dan apliksi pupuk hayati konsorsium di sawah. Hasil kegiatan ini adalah 20 orang petani memahami peran mikroba dan pupuk kotoran ternak serta komps dalam produksi tanaman; tetapi mereka belum mampu membuat pupuk organik sesuai standard. Hanya satu orang petani yang mengaplikasikan pupuk hayati disertai penambahan kompos di tanah sawah sehingga meningkatkan produksi sebesar $1 \%$. Program ini memberikan gambaran bahwa teknologi pupuk hayati dapat diadopsi oleh petani di Kecamatan Sukaratu.
\end{abstract}

Kata kunci: bahan organik; kotoran ternak; padi sawah; pupuk hayati.

\begin{abstract}
Some of the paddy fields in Sukaratu Sub-district, Tasikmalaya Regency were buried by Mount Galunggung's eruption material in 1982 so that the quality of soil was worse than that before the eruption. Improving the quality of paddy soil can be established with biological fertilizers. The purpose of this community service was to introduce the basic knowledge about biofertilizer to farmers in the Sinagar and Linggajati Village; and to improve farmers' skills in the application of biological fertilizers and compost. To achieve the goals, we conducted a focused group discussion, short extension program on biological fertilizers, compost production, and consortium biofertilizer application in paddy fields. The result verified that 20 farmers has knowledge about the role of beneficial microbes, manure and compost for plant production but they did not able to prepare standardized organic matter. However one farmer was interested to apply biofertilizers along with compost to paddy fields. This program illustrates that biofertilizer technology can be adopted by farmer in Sukaratu Sub-district.
\end{abstract}

Key Words: biofertilizer; cattle manure; organic matter; paddy soil 


\section{PENDAHULUAN}

Di sentra padi Kabupaten Tasikmalaya Jawa Barat, Kecamatan yang juga terkena dampak letusan Gunung Galunggung 1982 adalah Sukaratu. Setelah letusan, pasir diangkat dari atas sawah dan saat ini lahan sawah tersingkap tetapi mengandung material piroklastik yang tidak dapat diserap tanaman. Sawah telah direhabilitasi dan berproduksi antara 4-6 t/ha, lebih rendah dari produksi rata-rata padi di Tasikmalaya (6,9 t/ha) dan Jawa Barat yaitu 6,2 t/ha BPS, 2017). Upaya yang perlu dilakukan untuk meningkatkan kualitas tanah adalah dengan meningkatkan dan memobilisasi unsur hara makro.

Petani di kedua desa telah melakukan pemupukan anorganik namun belum melakukan pemupukan organik intensif. Teknologi pupuk hayati, perlu menjadi input karena mikroba berperan penting dalam siklus unsur hara dan mensuplai fitohormon (Bhattacharjee and Dey, 2014). Aplikasi pupuk hayati harus diikuti dengan pemberian bahan organik yang menjadi sumber karbon. Bahan organik limbah pertanian berupa jerami dan kotoran ternak melimpah di kedua desa karena tetapi petani belum biasa mengomposkannya sesuai standard. Peternakan sapi yang berkembang di kedua desa sangat memungkinan percepatan sistem pemupukan berimbang yang terdiri atas pupuk anorganik, organik dan hayati.

Pupuk hayati mengandung mikroba fungsional tanah sebagai penyedia unsur hara untuk tanaman (Simanungkalit et al., 2006). Aplikasi pupuk hayati terbukti mendukung pertumbuhan tanaman melalu mekanisme produksi hormon tumbuh (Bhattacharjee and Dey, 2014). Pupuk Organik berpotensi mengurangi penggunaan pupuk kimia, mengurangi residu pestisida, serta meningkatkan kualitas dan hasil panen (Lubis, 2004).

Sistem integrasi tanaman-ternak untuk padi akan meningkatkan keamanan pangan (Yuliani, 2014). Penerapan sistem ini perlu diperkuat dengan meningkatkan pengetahuan dan pemahaman petani mengenai konversi limbah pertanian dan ternak menjadi pupuk termasuk di dalamnya pupuk hayati. Kemampuan aplikasi pupuk hayati di sawah diperlukan untuk optimasi siklus unsur hara tanah dan selanjutnya hasil tanaman (Itelima et al., 2018). Pengabdian kepada Masyarakat ini bertujuan untuk memberikan pengetahuan dasar tentang pupuk hayati kepada petani serta meningkatkan keterampilan petani dalam aplikasi pupuk hayati disertai kompos.

\section{METODE PENELITIAN}

Program pengabdian kepada masyarakat dilakukan di Desa Sinagar dan Linggarjati Kecamatan Sukaratu Kabupaten Tasikmalaya, pada bulan Juni-Desember 2015. Peserta kegiatan adalah 20 orang petani, tiga orang staf Balai Penyuluh Pertanian (BPP) dan dua orang staf Kecamatan Sukaratu (gambar 1). 


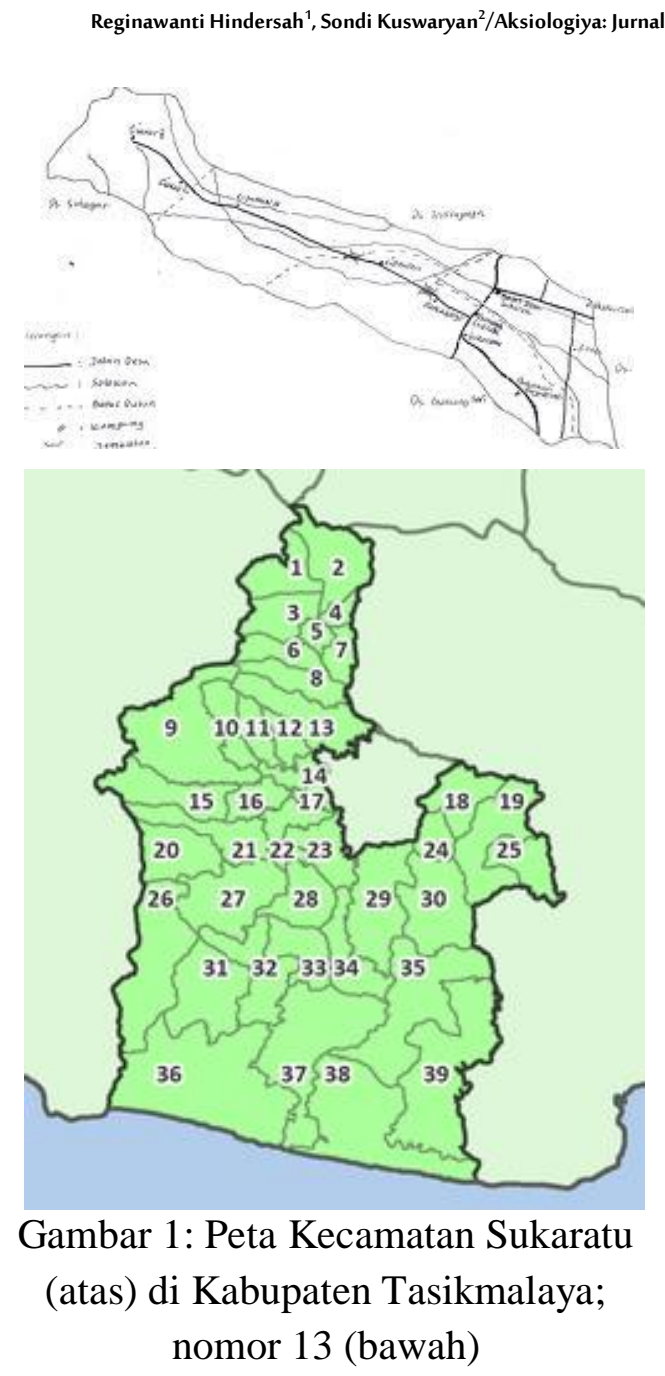

\section{Diskusi Kelompok Terfokus}

Tiga fokus utama diskusi ini adalah mendapatkan data dasar pemanfaatan bahan organik untuk pertanian, memaparkan materi mengenai bahan organik/kompos, pupuk hayati dan pemupukan berimbang, serta menginventarisasi pendapat petani terkait potensi aplikasinya. Diskusi dilakukan dua kali yaitu sebelum dan saat pelaksanaan kegiatan.

Materiyang disajikan dalam bentuk slide dan leaflet terdiri atas 1) kebutuhan nutrisi untuk tanaman; 2) pentingnya pupuk hayati ( $\mathrm{PH})$ dan 3) perbedaan $\mathrm{PH}$ dengan pupuk anorganik serta organik; 4) mikroba sebagai komponen utama $\mathrm{PH}$; dan 5) jenis dan metode pembuatan $\mathrm{PH}$; pentingnya bahan organik untuk kesehatan tanah sawah dipaparkan secara terperinci. Diskusi tentang bahan organik meliputi ulas balik tentang kompos dan metode pengomposan.

\section{Praktek Pembuatan Kompos}

Praktek pembuatan kompos jerami padi dilakukan di feed-lot peternakan sapi di desa Linggarjati. Komposisi bahan mpos adalah 70\% jerami padi, $20 \%$ campuran tanaman perdu legum dan rumput, $10 \%$ pupuk kotoran sapi kondisi setengah matang, dan $1 \%$ deda. Volume seluruh bahan kompos adalah sekitar $3 \mathrm{~m}^{3}$ yang ditumpuk sampai ketinggian $1 \mathrm{~m}$ di bagian tengah. Bagian atas campuran bahan diperciki oleh aktivator yang mengandung bakteri dan fungi heterotrof.

\section{Aplikasi Bahan Organik dan Pupuk Hayati}

Plot untuk aplikasi PH seluas $1.200 \mathrm{~m}^{2}$ terdiri atas 3 hamparan yang dipisahkan oleh satu hamparan sawah non demplot (Gambar 2). Lahan yang digunakan adalah hamparan di bawah Kelompok Tani Mupakat di desa Tawang Banteng, Pupuk hayati yang diaplikasi pada plot 1 dan 3 adalah $\mathrm{PH}$ konsorsium padat dan cair yang diformulasi oleh Laboratorium Biologi Tanah Unpad. Padi var. Ciherang ditanam jajar legowo tanpa pestisida. Plot 2 adalah pertanaman padi konvensional yang digunakan sebagai kontrol (Gambar 2). 
Reginawanti Hindersah' ${ }^{1}$, Sondi Kuswaryan²/Aksiologiya: Jurnal Pengabdian Kepada Masyarakat. Vol.4, No.1, Februari 2020 Hal 1 - 8

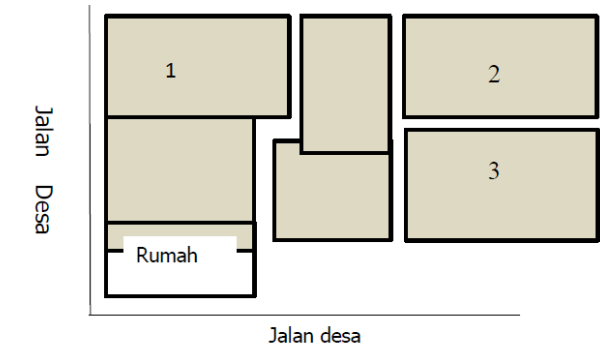

Gambar 2: Aplikasi pupuk hayati BION-UP dilakukan di plot no 1 dan 3 sedangkan plot 2 dijadikan kontrol tanpa pupuk hayati

Bibit ditanam dengan metode legowo dua-dua pada jarak tanam 20x20 cm antar bibit dan $30 \mathrm{~cm}$ (Babihoe, 2013), satu lubang ditanam 3-4 bibit. Pemupukan yang dilakukan pada plot perlakuan adalah:

1. Pupuk organik berasal dari petrokimia Gresik saat pengolahan tanah. Pupuk ini bersatu dengan sisa tanaman padi.

2. Pupuk anorganik terdiri atas urea dengan dosis $100 \mathrm{~kg} / \mathrm{ha}$, SP36 dengan dosis $100 \mathrm{~kg} / \mathrm{ha}$, dan NPK Phonska $200 \mathrm{~kg} / \mathrm{ha}$ berdasarkan dosis rekomendasi BB Padi Pemupukan dilakukan tiga kali yaitu:

a. awal tanam $1 / 3$ dosis urea, $1 / 2$ dosis SP36 dan 1/3 dosis NPK.

b. Pada 14 HST sebanyak 1/3 dosis urea dan $1 / 2$ dosis NPK

c. Pada 27 HST sebanyak 1/3 dosis urea.

3. $\mathrm{PH}$ padat $2 \mathrm{~kg}$ diberikan setelah tanam dengan cara dicampurkan dengan abu sekam sebanyak $10 \mathrm{~kg}$ dan disebar di permukaan tanah

4. $\mathrm{PH}$ cair dengan dosis $1 \%$ sebanyak 2 L/ha disemprotkan saat tanaman umur $1,2,3,4$, dan 5 minggu.

5. Plot dengan $\mathrm{PH}$ diberi pupuk anorganik $1 / 2$ dosis rekomendasi.

\section{HASIL DAN PEMBAHASAN}

Penjelasan mengenai pupuk hayati dan kompos saat diskus kelompok diawali dengan empat pertanyaan, yaitu:

1. Apakah sudah mengetahui pupuk hayati?

2. Apakah selalu membenamkan bahan organik saat pengolahan sawah?

3. Apakah pernah membuat Mikroorganisme Lokal (MOL) dan mengaplikasikannya untuk padi?

4. Apakah selalu menggunakan pupuk anorganik?

Petani peserta sudah terbiasa mengaplikasikan sisa tanaman tanpa pengomposan dan pupuk anorganik terutama NPK Phonska. Kompos diaplikasikan hanya jika mendapatkan bantuan pemerintah. Hanya seorang petani pernah memubuat MOL walaupun seluruh peserta mengetahui apa itu MOL. Tiidak ada peserta yang mengetahui $\mathrm{PH}$ sehingga materi itu dijelaskan menyeluruh.

Beberapa tokoh tani memiliki pengetahuan yang baik tentang cara dan manfaat pemupukan. Di Desa Sinagar ada sawah dengan hasil $7 \mathrm{t} / \mathrm{ha}$ bahkan 9 t/ha tetapi di Desa Linggajati hanya 4-5 t/ha. Produksi yang lebih baik di Sinagar disebabkan oleh kadar fraksi liat dari material gunung Galunggung yang lebih tinggi daripada Linggajati. Mineral liat 
memiliki muatan negatif yang berperan dalam penyediaan unsur hara tanaman (Crouse, 2018).

Perubahan yang terjadi setelh diksusi adalah (1) peningkatan pengetahuan petani tentang pupuk hayati dan (2) pemahaman tentang kelemahan dan kelebihan pupuk organik, hayati dan pupuk anorganik serta kesuburan tanah. Dari 25 peserta, ada tiga orang peserta yang ingin mencoba aplikasi pupuk hayati. Mereka adalah satu orang petani dan dua orang penyuluh pertanian dari BPP. Mereka akan mengaplikasikan PH dan kompos desa Tawangbanteng.

\section{Pengomposan}

Pada hari ke lima, suhu di dalam tumpukan kompos sudah meningkat sampai sekitar $60^{\circ} \mathrm{C}$ dan dilakukan pembalikan pertama. Pengomposan dilakukan selama satu bulan dengan tiga kali pembalikan lagi. Akibat komunikasi yang kurang baik, kompos ini langsung digunakan oleh petani padi sawah. Padahal dalam rencana, sebelum aplikasi, kompos akan dianalisis untuk memperoleh data kualitas kompos. Selain

penggunaan mesin rajang, praktek pembuatan kompos tidak banyak memberikan perubahan para peserta. Mungkin praktek pengomposan ini akan lebih berdampak terhadap peningkatan pengetahuan jika analisis sifat fisik dan kimia kompos terlaksana.

\section{Produksi Padi setelah Aplikasi Pupuk Hayati}

Sekitar 30-35 hari setelah tanam seluruh tanaman lahan 1 (dengan pupuk hayati) yang telah membentuk malai diserang tikus sehingga tidak dapat dipanen. Serangan tikus tidak menyebar ke lahan demplot lainnya. Selama budidaya padi, tanaman tidak pernah kekurangan air. Meskipun aplikasi pupuk hayati hanya dilakukan oleh seorang petani namun dua orang staf BPP Sukaratu turut membantu sampai panen (Gambar 3)

Hasil panen memperlihatkan bahwa dengan pemeliharaan intensif, produktivitas padi dengan kedua metode mencapai lebih dari $7 \mathrm{t} / \mathrm{ha}$. Perbedaan hasil antara petak kontrol dan petak aplikasi pupuk hayati hanya 0,9 t/ha; setara dengan peningkatan produktivitas sebesar $1,25 \%$ (Tabel 1).

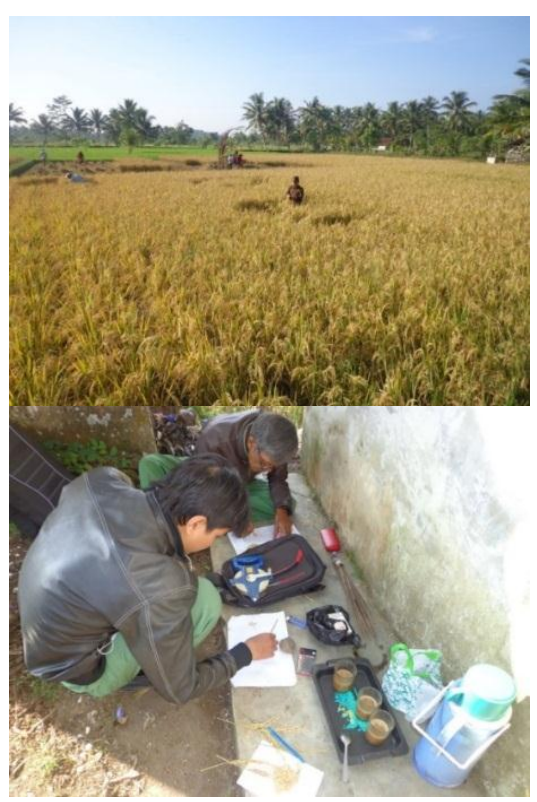

Gambar 3: Panen dengan metode ubinan (kiri) disertai pengamatan terhadap komponen hasil padi (kanan) 
Tabel 2. Produktivitas padi varietas Ciherang yang ditanam dengan pupuk organik dan pupuk hayati

\begin{tabular}{|c|l|l|l|}
\hline No. & \multicolumn{1}{|c|}{ Variabel Pengamatan } & Petak Kontrol & \multicolumn{1}{|c|}{ Petak Uji Coba } \\
\hline 1 & Tinggi Tanaman & $103 \mathrm{~cm}$ & $103 \mathrm{~cm}$ \\
\hline 2 & Jumlah Anakan & 21 anakan & 23 anakan \\
\hline 3 & Jumlah Rumpun & 128 rumpun & 128 rumpun \\
\hline 4 & Panjang Malai & $22 \mathrm{~cm}$ & $23 \mathrm{~cm}$ \\
\hline 5 & Jumlah Bulir Bernas/Malai & $129 \mathrm{bulir}$ & $157 \mathrm{bulir}$ \\
\hline 6 & Jumlah Bulir Hampa/Malai & $35 \mathrm{bulir}$ & $19 \mathrm{bulir}$ \\
\hline 7 & Hasil Ubinan & $4,77 \mathrm{~kg}$ & $4,83 \mathrm{~kg}$ \\
\hline 8 & Produktivitas/ha & $76,32 \mathrm{Kuintal}$ & $77,28 \mathrm{kuintal}$ \\
\hline
\end{tabular}

Komponen pertumbuhan yaitu tinggi tanaman, jumlah anakan serta rumpun padi di petak uji coba tidak berbeda dengan control. Namun berdasarkan komponen generatif tanaman yaitu jumlah bulir bernas dan hampa per malai menunjukkan bahwa Pupuk organik dan PH lebih baik. Hasil tanaman meningkat.

Para petani peserta lainnya telah mendapatkan informasi tersebut di atas dan mendapatkan bukti bahwa penurunan dosis pupuk anorganik sangat mungkin dilakukan jika pupuk organik dan hayati diaplikasikan.

\section{Indikator Keberhasilan Program}

Capaian program ini belum seperti yang diharapkan saat pelaksana PKM menentukan indikator keberhasilan kegiatan (Tabel 2). Jarak yang relatif dari jauh menyebabkan komunikasi langsung dan interaksi dengan para petani dan staf BPP sebagai pendamping petani, tidak optimal padahal pendampingan akan mempengaruhi keberhasilan adopsi teknologi padi selain komunikasi (Adawiyah et al., 2017).

Tabel 2. Indikator keberhasilan kegiatan

\begin{tabular}{|c|l|l|l|}
\hline No & \multicolumn{1}{|c|}{ Indikator } & \multicolumn{1}{c|}{ Target pencapaian } & \multicolumn{1}{c|}{ Pencapaian } \\
\hline 1 & Petani dengan pengetahuan PH & 25 orang & 23 orang \\
\hline 2 & Petani membuat kompos & 4 orang & 0 \\
\hline 3 & Peningkatan kualitas kompos & $\begin{array}{l}\text { Minimal kadar unsur hara N, } \\
\text { P, K; kadar air memenuhi } \\
\text { standard SNI }\end{array}$ & $\begin{array}{l}\text { Tidak } \\
\text { terpenuhi }\end{array}$ \\
\hline 4 & Petani yang mengaplikasikan PH & 2 orang & 1 orang \\
\hline 5 & Peningkatan produktivitas padi & $3 \%$ & $1,25 \%$ \\
\hline
\end{tabular}

\section{SIMPULAN}

Simpulan penerapan tekologi pemupukan organik dan hayati adalah sebagai berikut.

1. Kegiatan Diskusi Kelompok Terfokus memberi pengetahuan awal mengenai pentingnya pupuk organik dan pupuk hayati untuk peningkatan produksi padi, karena sebelum FGD seluruh peserta tidak mengenal pupuk hayati. 
Reginawanti Hindersah ${ }^{1}$, Sondi Kuswaryan²/Aksiologiya: Jurnal Pengabdian Kepada Masyarakat. Vol.4, No.1, Februari 2020 Hal 1 - 8

2. Praktek pembuatan kompos membuka wawasan petani dan tokoh tani desa Sinagar, Linggarjati dan Tawangbanteng mengenai penggunaan mesin perajang bahan baku dan pemberian mikroba aktivator di awal pengomposan.

3. Uji coba aplikasi kompos dan PH memberi bukti kepada petani bahwa penurunan dosis pupuk anorganik dapat dilakukan jika kompos dan PH diaplikasikan. Penurunan dosis ini tidak menurunkan hasil, bahkan meningkatkan hasil $1,25 \%$. Dengan demikian, terdapat potensi pengurangan alokasi dana input produksi padi karena harga pupuk hayati yang diaplikasikan relatif murah.

4. Hanya satu orang orang petani ingin dan mengaplikasikan pupuk hayati di sawah. Bahan organik yang dihasilkan tidak memenuhi standard (PP 70 tahun 2011) petani belum biasa dan belum ingin membuat kompos.

Perubahan perilaku yang diharapkan tidak mungkin terjadi hanya dari dua kali FGD dan beberapa sesi praktek. Diperlukan pendampingan atau kehadiran personal "agen perubahan" yang secara rutin, dalam keseharian petani, memberikan teladan dan bersamasama memproduksi kompos. Petani yang telah terlibat dalam uji coba diharapkan dapat menginformasikan pengalamannya dan menularkan keterampilan aplikasi kompos dan pupuk hayati.
UCAPAN TERIMAKASIH

Kami berterimakasih kepada Kepala Balai Penyuluhan Pertanian di Kecamatan Sukaratu atas fasilitasi dan peran serta selama pelaksanaan PKM. Program ini dibiayai oleh Universitas Padjadjaran.

\section{DAFTAR PUSTAKA}

Adawiyah, C.R., Sumardjo, Mulyani E.S. 2017. Faktor-Faktor yang Memengaruhi Peran Komunikasi Kelompok Tani Dalam Adopsi Inovasi Teknologi Upaya Khusus (Padi, Jagung, Dan Kedelai) di Jawa Timur. J. Agro Ekonomi, 35(2): 151-170

Badan Pusat Statistik. 2017. Provinsi Jawa Barat Dalam Angka. BPS Provinsi Jawa Barat. Bandung Bhattacharjee, R. and Dey, U. 2014. Biofertilizer, A Way toward Organic Fertilizer: A Review. Afr. J. Microbiol. Res., 8(24):2332-2342

Bobihoe, J. 2013. Sistem Tanam Padi Jajar Legowo. Badan Pengkajian Teknologi Pertanian Jam-bi. Jambi

Crouse. M. 2018. Soils and Plant Nutrients. NC State Extension Publications.

https://content.ces.ncsu.edu/exte nsion-gardener-handbook/1soils-and-plant-nutrients. [25/09/207]

Itelima J.U., Bang W.J. Sila M.D., Onyimba, I.A. and Egbere, O.J. 2018. A review: Biofertilizer - $A$ key player in enhancing soil fertility and crop productivity. Direct Res. J. Agric. Food Sci, 6(3): 73-83

Lubis, I. 2004. Pertanian Organik untuk Meminimalisir Residu Pestisida pada Produk Pertanian 
Reginawanti Hindersah'1 , Sondi Kuswaryan²/Aksiologiya: Jurnal Pengabdian Kepada Masyarakat. Vol.4, No.1, Februari 2020 Hal 1 - 8

dan undang-Undangnya. Prosiding Seminar Parasitologi dan Toksikologi Veteriner. Hal 89-106.

Simanungkalit, R.D.M., Suriadikarta, D.A., Saraswati, R., Setyorini, D., Hartatik, W. 2006. Pupuk Organik dan Pupuk Hayati. Balai
Besar Litbang Sumberdaya Lahan Pertanian. Balai Penelitian dan Pengembangan Pertanian. Bogor.

Yuliani. 2014.Sistem integrasi padi ternak untuk mewujudkan kedaulatan pangan. J. Agroteknologi 4(2):15-26. 